\title{
ANALISIS STUDI GERAKAN DAN SIMULASI ANTRIAN UNTUK PENINGKATAN PRODUKTIVITAS PADA PELAYANAN SERVIS MOTOR
}

\author{
Hendy Tannady dan Erwin Adianto \\ Program Studi Teknik Industri, Fakultas Teknologi \& Desain, Universitas Bunda Mulia \\ e-mail: hendytannady@yahoo.com
}

\begin{abstract}
ABSTRAK
Saat ini perusahaan produk maupun jasa menghadapi persaingan yang sangat ketat. Seiring berjalannya waktu semakin besar keinginan dan kebutuhan konsumen. Ketika konsumen menginginkan kualitas yang makin baik maka industri harus mengurangi biaya dan berbagai aspek penunjang lainnya. Salah satu yang paling mendasar adalah peningkatan produktivitas karyawan. Produktivitas karyawan dinilai sebagai salah satu faktor penting dalam menjalankan usaha baik perusahaan produk maupun jasa. Secara umum adanya produktivitas dilihat dari output yang dihasilkan dan dapat dimodifikasi hasilnya seperti waktu yang lebih singkat dan sebagainya. Karyawan yang memiliki output paling besar dalam jumlah waktu yang ditentukan dapat dikategorikan sebagai karyawan yang produktif maupun sebaliknya. Penelitian menggunakan pengamatan peta tangan kanan dan kiri serta simulasi antrian dalam mengoptimumkan waktu yang dihasilkan. Setelah melakukan serangkaian improvisasi pada gerakan tangan kanan dan kiri, diperoleh peningkatan produktivitas sebesar 17\% pada lini servis pit biasa dan 12\% (6 motor menjadi 8 motor) pada lini high end pit (4 motor menjadi 5 motor).
\end{abstract}

Kata Kunci: Produktivitas, Simulasi Antrian, Optimum.

\begin{abstract}
At present the company products and services face a very tight competition. Over time the greater the desire and needs of consumers. When consumers want the better quality then the industry must reduce costs and various other supporting aspects. One of the most fundamental is to increase employee productivity. Productivity of employees rated as one of the important factors in running a business both companies products or services. In general, the presence of productivity seen from the output produced and can be modified as a result a shorter time and so on. Employees have the greatest output in a specified amount of time that can be categorized as a productive employee and vice versa. Research using observational map left and right hands and the simulation time queue in optimizing generated. After conducting a series of improvisations on the right and left hand movements, obtained an increase in productivity by $17 \%$ on the usual pit service line and 12\% (6 to 8 motor bikes) at the high end line of the pit (4 to 5 a motor bikes).
\end{abstract}

Keywords: Productivity, Queue Simulation, Optimum.

\section{PENDAHULUAN}

Perkembangan dunia perindustrian saat ini semakin pesat baik dalam dunia manufaktur produk maupun jasa. Berkembangnya perindustrian ini sangat memberikan dampak yang positif bagi negara maupun perusahaan sendiri baik langsung maupun tidak langsung. Berkembangnya dunia industri juga mengakibatkan persaingan yang ketat antar para pelaku industri dan hal ini tentu menjadi masalah terbesar dalam melihat pangsa pasar dan daya saing perusahaan.

Untuk membuat sebuah perusahaan berkembang dan maju dengan pesat, dibutuhkan sumber daya yang terbaik dan optimal penggunaannya. Sumber daya yang dimaksud adalah sumber daya alam yang kita olah seperti bahan mentah (raw material) dan bahan bakar serta sumber daya manusia yang biasanya menjadi yang mengolah bahan mentah atau sumber daya alam tersebut. Sumber daya alam yang baik akan diolah oleh sumber daya manusia menjadi sebuah produk dengan nilai tambah yang lebih dan berguna bagi masyarakat.

Salah satu faktor yang menarik adalah produktivitas karyawan. Karyawan yang produktif akan melakukan pekerjaannya dengan optimal dan sesuai dengan peraturan yang ada. Adanya perhitungan produktivitas karyawan akan menentukan apakah karyawan ini melakukan pekerjaannya sesuai dengan job description yang telah ditetapkan perusahaan. Mengenai antrian, pada beberapa perusahaan dapat menjadi sebuah parameter yang menentukan apakah karyawan produktif atau 
tidak. Apabila dilihat dari sisi antrian, antrian yang memiliki waktu yang cepat prosesnya maka dapat dikatakan produktifitas karyawan baik dengan opsi seperti karyawan melakukan job desc dengan baik, karyawan sudah dilatih terlebih dahulu, karyawan sudah terbiasa, dan karyawan sudah memiliki tingkat pendidikan yang memadai.

Latar belakang dari penelitian adalah upaya untuk meningkatkan produktivitas dari karyawan dengan melakukan improvisasi terhadap studi gerakan dan melakukan komparasi hasilnya dengan simulasi antrian.

\section{TINJAUAN PUSTAKA}

Keseimbangan lini perakitan (line balancing) merupakan suatu metode penugasan pekerjaan ke dalam stasiun kerja-stasiun kerja yang saling berkaitan dalam satu lini produksi sehingga setiap stasiun kerja memiliki waktu yang tidak melebihi waktu siklus stasiun kerja tersebut. Keseimbangan lini perakitan (line balancing) adalah upaya untuk meminimumkan ketidakseimbangan diantara mesin-mesin atau personil untuk mendapatkan waktu yang sama di setiap stasiun kerja sesuai dengan kecepatan produksi yang diinginkan [1]. Kriteria umum keseimbangan lintasan perakitan adalah memaksimumkan efisiensi dan meminimumkan balance delay. Tujuan utama dari penggunaan metode line balancing ini adalah untuk mengurangi atau meminimumkan waktu menganggur (idle time) pada lintasan yang ditentukan oleh operasi yang paling lambat [2]. Selain itu, tujuan perencanaan keseimbangan lintasan adalah mendistribusikan unit-unit kerja atau elemen-elemen kerja pada setiap stasiun kerja agar waktu menganggur dari stasiun kerja pada suatu lintasan produksi dapat ditekan seminimal mungkin sehingga pemanfaatan dari peralatan maupun operator dapat digunakan semaksimal mungkin [2].

Kegunaan dari pengukuran kerja secara garis besar adalah untuk menetapkan waktu standar untuk sebuah pekerjaan. Standar tersebut digunakan untuk 4 alasan berikut ini:

1. Untuk menjadwalkan pekerjaan dan alokasi kapasitas. Semua penjadwalan mengacu untuk mendapatkan estimasi berapa lama waktu yang dibutuhkan untuk melakukan suatu pekerjaan

2. Untuk menyediakan dasar dari tujuan untuk memotivasi tenaga kerja dan mengukur tingkat performa pekerja. Standar yang sudah terukur sangat kritis karena menentukan insentif yang dikeluarkan

3. Untuk mendapatkan kontrak baru dan mengevaluasi performa dari yang sebelumnya.

4. Untuk menyediakan perbandingan untuk peningkatan. Sebagai tambahan untuk evaluasi internal, tim pembanding secara umum akan membandingkan standar kerja di perusahaan mereka dengan standar kerja yang sama di organisasi kerja lainnya.

Pengukuran kerja dan standar hasil kerjanya menjadi kontroversial di era Taylor. Mayoritas kritikus ini berasal dari sebuah kumpulan, dimana berargumen dimana manajerial sering menetapkan standar yang secara umum tidak dapat dicapai. Ada juga argumen dimana pekerja yang mendapat cara yang lebih baik dalam bekerja sering kali mendapat hukuman (rate cutting).

Antrian adalah suatu kejadian yang biasa dalam kehidupan sehari-hari. Menunggu di depan loket untuk mendapatkan tiket kereta api atau tiket bioskop, pada pintu jalan tol, pada bank, pada kasir supermarket, dan situasisituasi yang lain merupakan kejadian yang sering ditemui. Studi tentang antrian bukan merupakan hal yang baru.

Antrian timbul disebabkan oleh kebutuhan akan layanan melebihi kemampuan (kapasitas) pelayanan atau fasilitas layanan, sehingga pengguna fasilitas yang tiba tidak bisa segera mendapat layanan disebabkan kesibukan layanan. Pada banyak hal, tambahan fasilitas pelayanan dapat diberikan untuk mengurangi antrian atau untuk mencegah timbulnya antrian. Akan tetapi biaya karena memberikan pelayanan tambahan, akan menimbulkan pengurangan keuntungan mungkin sampai di bawah tingkat yang dapat diterima. Sebaliknya, sering timbulnya antrian yang panjang akan mengakibatkan hilangnya pelanggan/nasabah.

Salah satu model yang sangat berkembang sekarang ini ialah model 
matematika. Umumnya, solusi untuk model matematika dapat dijabarkan berdasarkan dua macam prosedur, yaitu: analitis dan simulasi. Pada model simulasi, solusi tidak dijabarkan secara deduktif. Sebaliknya, model dicoba terhadap harga-harga khusus variabel jawab berdasarkan syarat-syarat tertentu (sudah diperhitungkan terlebih dahulu), kemudian diselidiki pengaruhnya terhadap variabel kriteria. Karena itu, model simulasi pada hakikatnya mempunyai sifat induktif. Misalnya dalam persoalan antrian, dapat dicoba pengaruh bermacam-macam bentuk sistem pembayaran sehingga diperoleh solusi untuk situasi atau syarat pertibaan yang mana pun. berikut:

Komponen dasar antrian adalah sebagai

1. Kedatangan

Setiap masalah antrian melibatkan kedatangan, misalnya orang, mobil, panggilan telepon untuk dilayani, dan lainlain. Unsur ini sering dinamakan proses input. Proses input meliputi sumber kedatangan atau biasa dinamakan calling population, dan cara terjadinya kedatangan yang umumnya merupakan variabel acak. Variabel acak adalah suatu variabel yang nilainya bisa berapa saja sebagai hasil dari percobaan acak. Variabel acak dapat berupa diskrit atau kontinu. Bila variabel acak hanya dimungkinkan memiliki beberapa nilai saja, maka ia merupakan variabel acak diskrit. Sebaliknya bila nilainya dimungkinkan bervariasi pada rentang tertentu, ia dikenal sebagai variabel acak kontinu [3].

2. Pelayanan

Pelayan atau mekanisme pelayanan dapat terdiri dari satu atau lebih pelayan, atau satu atau lebih fasilitas pelayanan. Tiap-tiap fasilitas pelayanan kadang-kadang disebut sebagai saluran (channel) [4]. Contohnya, jalan tol dapat memiliki beberapa pintu tol. Mekanisme pelayanan dapat hanya terdiri dari satu pelayan dalam satu fasilitas pelayanan yang ditemui pada loket seperti pada penjualan tiket di gedung bioskop.

3. Antri

Inti dari analisis antrian adalah antri itu sendiri. Timbulnya antrian terutama tergantung dari sifat kedatangan dan proses pelayanan. Jika tak ada antrian berarti terdapat pelayan yang menganggur atau kelebihan fasilitas pelayanan [5].

Penentu lainnya yang penting adalah disiplin antri. Disiplin antri adalah aturan keputusan yang menjelaskan cara melayani pengantri. Ada 5 bentuk disiplin pelayanan yang biasa digunakan, yaitu [6]:

1. First-Come First-Served (FCFS) atau First-In First-Out (FIFO) artinya, lebih dulu datang (sampai), lebih dulu dilayani (keluar). Misalnya, antrian pada loket pembelian tiket bioskop.

2. Last-Come First-Served (LCFS) atau Last-In First-Out (LIFO) artinya, yang tiba terakhir yang lebih dulu keluar. Misalnya, sistem antrian dalam elevator untuk lantai yang sama.

3. Service In Random Order (SIRO) artinya, panggilan didasarkan pada peluang secara random, tidak soal siapa yang lebih dulu tiba.

Priority Service (PS) artinya, prioritas pelayanan diberikan kepada pelanggan yang mempunyai prioritas lebih tinggi dibandingkan dengan pelanggan yang mempunyai prioritas lebih rendah, meskipun yang terakhir ini kemungkinan sudah lebih dahulu tiba dalam garis tunggu. Kejadian seperti ini kemungkinan disebabkan oleh beberapa hal, misalnya seseorang yang dalam keadaan penyakit lebih berat dibanding dengan orang lain dalam suatu tempat praktek dokter. Ada 4 model struktur antrian dasar yang umum terjadi dalam seluruh sistem antrian, diantaranya:

\section{Single Channel-Single Phase}

Single Channel berarti hanya ada satu jalur yang memasuki sistem pelayanan atau ada satu fasilitas pelayanan. Single Phase berarti hanya ada satu pelayanan.

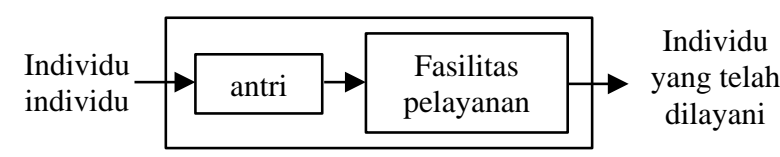

Gambar 1. Sistem Antrian Single ChannelSingle Phase 


\section{Single Channel-Multi Phase}

Istilah Multi Phase menunjukkan ada dua atau lebih pelayanan yang dilaksanakan secara berurutan (dalam phase-phase). Sebagai contoh: pencucian mobil.

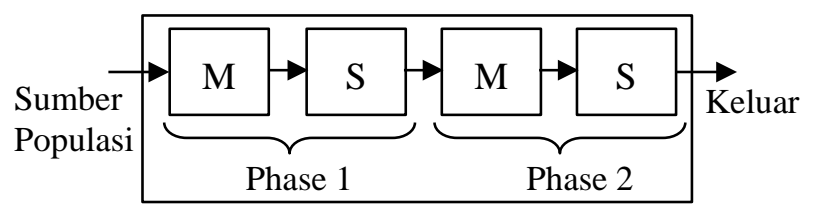

Keterangan:

$\mathrm{M}=$ antrian

$\mathrm{S}=$ fasilitas pelayanan

\section{Gambar 2. Sistem Antrian Single Channel- Multi Phase}

\section{Multi Channel-Single Phase}

Sistem Multi Channel-Single Phase terjadi kapan saja di mana ada dua atau lebih fasilitas pelayanan dialiri oleh antrian tunggal, sebagai contoh model ini adalah antrian pada teller sebuah bank.

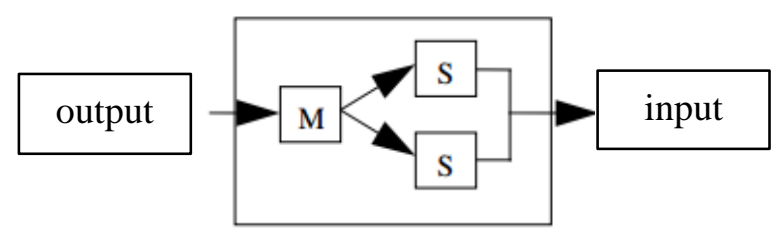

Gambar 3. Sistem Antrian Multi ChannelSingle Phase

4. Multi Channel-Multi Phase

Sistem Multi Channel-Multi Phase sebagai contoh, her registrasi para mahasiswa di universitas, pelayanan kepada pasien di rumah sakit mulai dari pendaftaran, diagnosa, penyembuhan sampai pembayaran. Setiap sistem-sistem ini mempunyai beberapa fasilitas pelayanan pada setiap tahapnya.

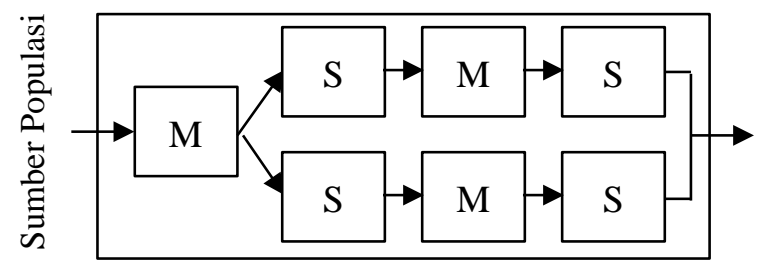

Gambar 4. Sistem Antrian Multi ChannelMulti Phase

\section{METODE PENELITIAN}

Penelitian dilakukan di sebuah unit servis dari sebuah perusahaan otomotif yang memproduksi kendaraan roda 2, penelitian mengamati waktu antrian dari kendaraan yang datang untuk dilayani, pengumpulan data dan pengamatan dibatasi hanya pada lini pit biasa dan high-end pit, dimana obyek yang diamati adalah tata cara kerja dari Service Advisor berjumlah 2 orang, Mekanik Pit Standar berjumlah 11 orang, Mekanik High End Pit berjumlah 5 orang, dan Mekanik Final Inspection berjumlah 2 orang.

Service Advisor adalah petugas yang melayani konsumen dengan mendengar keluhan dari konsumen dan mencatat dalam lembar PKB (Perintah Kerja Bengkel) yang nantinya digunakan oleh mekanik untuk menganalisis apa yang perlu diperbaiki. Mekanik Pit Standar adalah mekanik yang melakukan reparasi pada motor di bawah 250 cc, seperti motor bebek, matic, dan non injeksi. Mekanik High End Pit adalah mekanik yang melakukan reparasi motor besar di atas 250 cC, seperti CBR 250R, CBR 150R, PCX, CB 150R, dan motor injeksi lainnya. Mekanik final inspection adalah mekanik yang berada di ujung sistem dimana tugasnya adalah memeriksa dan menjamin bahwa motor telah diservis dengan baik dan siap untuk dibawa pulang oleh konsumen.

Metode pengolahan data menggunakan studi gerakan operator dan menggunakan datanya sebagai masukan bagi simulasi antrian untuk mengetahui dampak setelah improvisasi dilakukan.

\section{HASIL DAN PEMBAHASAN}

Setelah melakukan pengumpulan data di lapangan, melakukan berbagai analisis situasional dengan peekrja yang terlibat dan analisis terkait aplikasi teori Antrian, berikut adalah Hasil dan Pembahasan.

Dari data Tabel 1 dan Tabel 2 ditemukan kapasitas mekanik seperti ditunjukkan pada Tabel 3 dan Tabel 4. Dari hasil analisis ditemukan bahwa kapasitas rata-rata dari masing-masing pit yang diteliti adalah 6 unit untuk pit biasa dan 4 unit untuk high end pit. Terjadi waktu menunggu part yang lama dan besar sehingga mekanik mengalami idle dan 
waktu kerja 1 motor lebih lama. Beberapa usulan yang diharapkan adalah mengurangi beberapa kegiatan dan pelatihan serta perbaikan SOP yang diharapkan akan dapat mengurangi waktu yang ada saat ini.

Tabel 1. Kegiatan yang Terekam dan Waktunya Pit Biasa

\begin{tabular}{clr}
\hline No & \multicolumn{1}{c}{ Keterangan } & Waktu (Detik) \\
\hline 1 & Penerimaan & 27 \\
2 & Pengecekan Keluhan & 196 \\
3 & Pendistribusian Motor & 79 \\
4 & Servis Motor & 1951 \\
5 & Final Inspection & 174 \\
6 & Proses Akhir & 55 \\
7 & Proses Penyediaan Part & 1642 \\
\multicolumn{2}{r}{ TOTAL } & 4124 \\
\hline
\end{tabular}

Tabel 2. Kegiatan yang Terakan dan Waktunya pada High End Pit

\begin{tabular}{llr}
\hline No & \multicolumn{1}{c}{ Keterangan } & $\begin{array}{r}\text { Waktu } \\
\text { (Detik) }\end{array}$ \\
\hline 1 & Penerimaan & 27 \\
2 & Pengecekan Keluhan & 246 \\
3 & Pendistribusian Motor & 86 \\
4 & Servis Motor & 2287 \\
5 & Final Inspection & 219 \\
6 & Proses Akhir & 55 \\
7 & Proses Penyediaan Part & 2672 \\
\hline & TOTAL & 5592 \\
\hline
\end{tabular}

Tabel 3. Pit biasa

\begin{tabular}{clr}
\hline No & \multicolumn{1}{c}{ Keterangan } & Waktu \\
\hline 1 & Total waktu proses (detik) & 4124 \\
2 & Total waktu proses (menit) & 68,7 \\
3 & Waktu kerja (jam) & 6,7 \\
4 & Waktu kerja (menit) & 402 \\
5 & Kapasitas pekerja (motor) & 6 \\
\hline
\end{tabular}

Tabel 4. High End Pit

\begin{tabular}{clr}
\hline No & \multicolumn{1}{c}{ Keterangan } & Waktu \\
\hline 1 & Total waktu proses (detik) & 5592 \\
2 & Total waktu proses (menit) & 93,2 \\
3 & Waktu kerja (jam) & 6,7 \\
4 & Waktu kerja (menit) & 402 \\
5 & Kapasitas pekerja (motor) & 4 \\
\hline
\end{tabular}

Apabila diterapkan dan terjadi perubahan di beberapa sisi pelayanan, maka waktu yang akan didapat adalah seperti pada Tabel 5 . Sehingga kapasitas pelayanannya terlihat pada Tabel 6.

Terjadi peningkatan waktu servis pada pit biasa adalah $17 \%$ sehingga kapasitas dari 6 motor menjadi 8 motor dan pada high end pit terjadi peningkatan $12 \%$ lebih cepat sehingga kapasitas motor dari 4 menjadi 5 motor.

Tabel 5. Pit biasa dan High End Pit (Setelah Improvisasi)

\begin{tabular}{clrlr}
\hline \multirow{2}{*}{ No } & \multicolumn{2}{c}{ Pit Biasa } & \multicolumn{2}{c}{ High End Pit } \\
\cline { 2 - 4 } & \multicolumn{1}{c}{ Keterangan } & Waktu (Detik) & \multicolumn{2}{c}{ Waktu (Detik) } \\
\hline 1 & Penerimaan & 22 & Penerimaan & 27 \\
2 & Pengecekan Keluhan & 178 & Pengecekan Keluhan & 228 \\
3 & Pendistribusian Motor & 53 & Pendistribusian Motor & 86 \\
4 & Servis Motor & 1754 & Servis Motor & 1971 \\
5 & Final Inspection & 101 & Final Inspection & 116 \\
6 & Proses Akhir & 55 & Proses Akhir & 55 \\
7 & Proses Penyediaan Part & 742 & Proses Penyediaan Part & 1952 \\
\hline TOTAL & & 2905 & & 4435 \\
\hline
\end{tabular}

Tabel 6. Pit biasa dan High End Pit (Setelah Improvisasi)

\begin{tabular}{rlrlr}
\hline \multirow{2}{*}{ No } & \multicolumn{2}{c}{ Pit Biasa } & \multicolumn{2}{c}{ Kigh End Pit } \\
\cline { 2 - 5 } & \multicolumn{1}{c}{ Keterangan } & 2905 & Total waktu proses (detik) & Waktu \\
\hline 1 & Total waktu proses (detik) & 48.4166667 & Total waktu proses (menit) & 73.9166667 \\
2 & Total waktu proses (menit) & 6.7 & Waktu kerja (jam) & 6.7 \\
3 & Waktu kerja (jam) & 402 & Waktu kerja (menit) & 402 \\
4 & Waktu kerja (menit) & 8 & Kapasitas pekerja (motor) & 5 \\
5 & Kapasitas pekerja (motor) & & &
\end{tabular}




\section{KESIMPULAN}

Perubahan beberapa bagian seperti SOP, perubahan tiket antrian, perubahan tempat special tools dan pelatihan frontdesk untuk melakukan coding part yang lebih cepat dan tidak menunda pekerjaan akan menambah kapasitas dari mekanik sehingga pelayanan akan semakin cepat. Dari pembahasan ini juga menyimpulkan waktu proses yang lebih cepat dan waktu pelaynan yang lebih baik. Sehingga konsumen menunggu tidak lama dan jumlah yang diharapkan juga semakin baik.

\section{DAFTAR PUSTAKA}

[1]. Purnomo Hari, 2003, Pengantar Teknik Industri, Edisi 1, Cetakan 1, Graha Ilmu, Yogyakarta.
[2]. Baroto T, 2002, Perencanaan dan Pengendalian Produksi, Ghalia, Indonesia, Jakarta.

[3]. Levin, Richard I, dkk. 2002. Quantitative Approaches to Management (Seventh Edition). McGraw-Hill, Inc. New Jersey.

[4]. Schroeder, Roger G. 1997. Operations Management. McGraw-Hill, Inc. New Jersey.

[5]. Mulyono, S. 1991. Operations Research. FE-UI. Jakarta.

[6]. Siagian, P. 1987. Penelitian Operasional: Teori dan Praktek. Universitas Indonesia Press. Jakarta. 